\title{
The Indonesian-Australian Archaeological Research Project in the Northern Moluccas
}

\author{
Peter Bellwood
}

\section{Why the Northern Moluccas?}

The Indonesian-Australian Archaeological Research Project in the Northern Moluccas (the Indonesian Province of Maluku Utara), undertaken between 1990 and 1996, illuminated 40,000 years of prehistory in a biogeographical region widely known today as 'Wallacea', named after the pioneer naturalist and explorer Alfred Russel Wallace, author of The Malay Archipelago (Wallace 1869). Wallacea, for our purposes, lies between the Sunda and Sahul continental shelves, hence between Borneo/Bali and New Guinea/Australia. For R.E. Dickerson (1928), who first coined the term, Wallacea included the major Philippine and eastern Indonesian archipelagos, the latter comprising Sulawesi, Nusa Tenggara (the Lesser Sundas), Timor, and the Moluccas (Fig. 1.1). Many biogeographers since Dickerson have left out the Philippines (excluding Palawan) and the Moluccas from the definition of Wallacea (e.g. Whitmore 1981:xii), but this monograph is focused upon human rather than natural history. The 'full Wallacea' between the Sunda and Sahul continental shelves (or between Huxley's Line of 1868 and the combined Lydekker (1896) and Weber (1894) Lines, see George 1981: Fig. 2.4) is a far more useful and meaningful concept. No land bridges ever crossed the full expanse of this region of deep seas and steeply plunging coastlines during the Pleistocene Ice Ages, even during glacial maxima, and humans migrating from Taiwan or Sundaland towards New Guinea and Australia always had to cross sea gaps between islands to reach their goals. This monograph is focused on archaeological results from just one small group of islands within this intriguing Wallacean zone of animal and human biogeographical transition, a zone that has always formed both a bridge and a barrier between the Asian and Australian continents.

The original choice of these islands for archaeological research grew from much earlier observations and assumptions about the human prehistory of the Philippine, Indonesian and Oceanic islands, going back at least as far as the voyages of Captain Cook and others during the eighteenth century. By the time volume editor Peter Bellwood emigrated from England to New Zealand in 1967, the simple question Where did the Polynesians come from? had been entertaining scholars for a couple of centuries (Howard 1967). By 1967, the consensus had come firmly around to an origin for Polynesians somewhere in the northern islands of Southeast Asia, followed by migrations through Island Melanesia or Micronesia (Green 1967; Howells 1973a). Johann Reinhold Forster, therefore, with his 1770s linguistic and biological observations made during Cook's Second Voyage on similarities between Polynesians, Micronesians, Malays and Filipinos 
(Thomas et al. 1996:187), was somewhere close to being right in the opinions of the majority of mid-twentieth-century comparative linguists, physical anthropologists, blood group geneticists, and the small number of archaeologists working in tropical Oceania at that time.

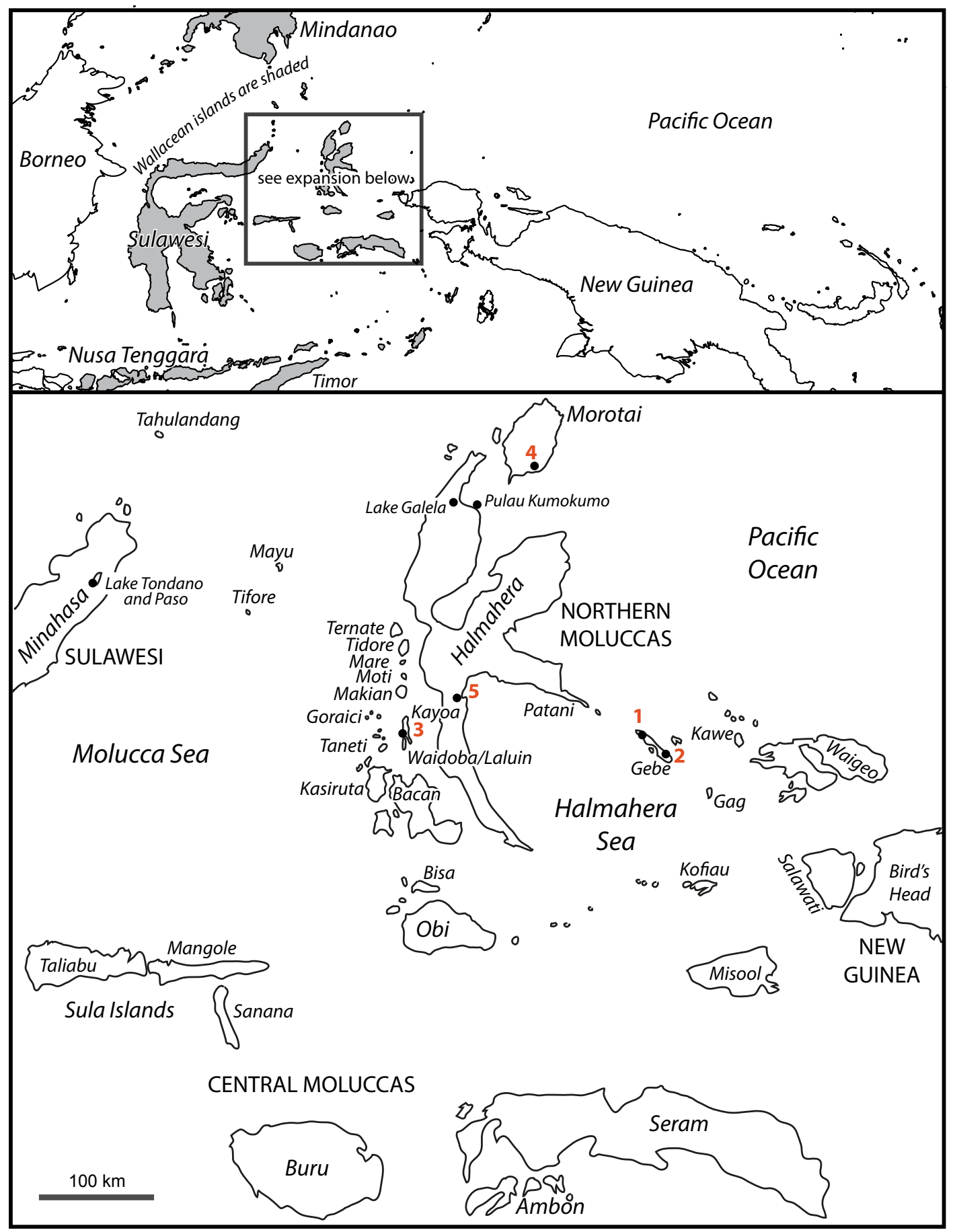

Figure 1.1 The eastern portion of Island Southeast Asia (the Wallacean islands as here defined are shaded) with details of the Northern Moluccas.

Sites and site groups as follows: 1) Golo, Wetef and Buwawansi; 2) Um Kapat Papo and Kaitutsi; 3) Uattamdi and Bukit Keramat; 4) Sabatai Tua, Daeo, Tanjung Pinang, and Sambiki Tua; 5) Gua Siti Nafisah.

Source: Peter Bellwood. 
Also by 1967, the Neolithic 'Lapita' decorated pottery style and associated cultural complex of Island Melanesia and western Polynesia (now dated c. 1200 to 800 BCE) had become the main weapon in the archaeological arsenal for those who wished to discuss Polynesian origins, and indeed the origins of all Austronesian-speaking populations in Roger Green's 'Remote Oceania', beyond New Guinea and the Solomons (Green 1991). The Lapita archaeological record at that time suggested very strongly that the first human colonists of the Tongan and Samoan islands in western Polynesia had arrived around 3000 years ago from Island Melanesia, especially Fiji, and went on to become the Polynesians of history as a result of cultural evolution within Tonga and Samoa during the following millennia (Green 1967).

But where were ancestral Polynesian populations located before they reached Fiji? This was not as clear in 1967 as it is now. W.W. Howells (1973a), for instance, was still at that time able to favour a Micronesian route for ancestral Polynesians out of Southeast Asia over the Melanesian one suggested by the Lapita archaeology (Lapita-style pottery has never been found in Micronesia, except for the Marianas; Carson et al. 2013). In a broader perspective, the prehistoric Polynesians were just one group, small in number but remarkably large in geographical distribution, within the vast population of Austronesian-language speakers who are today distributed from Madagascar to Easter Island. More relevant for any consideration of the Northern Moluccas in prehistory was the question Where did Lapita material culture develop, immediately prior to its arrival c. 3200 years ago in Melanesia? Given that Lapita sites were located mainly in Island Melanesia, was Lapita purely a home-grown Island Melanesian product with only minor diffusion from Island Southeast Asia, as some archaeologists continued to believe (Allen 1984; Spriggs 1984; Terrell et al. 2001), or did it develop in nascent form somewhere within Island Southeast Asia itself, as had often been suggested during the 1970s (Bellwood 1978; Golson 1972; Howells 1973a)?

In 1975, I published some early conclusions of my own on this issue in the pages of Current Anthropology (Bellwood 1975:13):

Lapita pottery seems likely to be attributable to a mobile group of Austronesian seafarers and traders who were expanding in central and eastern Melanesia after 1300 B.C. The degree of emphasis on dentate stamping appears to be a localized Melanesian development, but the general Lapita combinations of dentate stamping, circle stamping, red-slipping and lime infill, carinated body forms, and absence of painting, cord-marking, and tripod feet quite clearly link it with similar and contemporary ceramics in the Marianas (Spoehr 1957), in the Batungan sites on Masbate in the central Philippines (Solheim 1968: Fig. 5), and in the Yüan-shan culture in northern Taiwan (Chang 1969). There are no grounds at all for deriving the Lapita ceramic style from anywhere on the Southeast Asian mainland; there are clearly no close similarities with the Lungshanoid cultures of mainland China or Taiwan (Chang 1969), and the well-known Sa-huynh site in South Vietnam (Parmentier 1924, Solheim 1959) may perhaps be regarded as a record of Chamic settlement in South Vietnam from the Island Southeast Asian jar-burial province of the 1st millennium B.C. The Austronesian languages themselves have no traceable mainland origin, and, to keep closely to the point, there are no grounds for seeking possible extra-Melanesian connections for Lapita pottery beyond Taiwan, the Philippines, and northeastern Indonesia. It is possible to trace Yüanshan origins back to the earlier cord-marked and incised pottery of Taiwan, and this of course in turn may have a mainland origin (Chang 1969: chap. 10), but the relevance of this connection for Lapita origins remains to be demonstrated.

When I wrote this piece as a first draft in 1973, my main interest was to trace Lapita origins back into an archaeologically and linguistically documented trail of settlement extending eastward into Island Melanesia from eastern Indonesia and the Philippines, ultimately perhaps from a Neolithic and Proto-Austronesian homeland in Taiwan. My 1974 excavations with I Made Sutayasa in Minahasa and the Talaud Islands (Bellwood 1976) were my first fieldwork foray into this question. The research in the Northern Moluccas was basically a continuation of this, two decades later, with similar goals in mind. 
My basic views on the overall significance of Austronesian population and language dispersal have changed little since those years, despite variations in detail, and now receive support from the major growth in the quantity of available archaeological information from recent Neolithic excavations in Taiwan (e.g. Tsang and Li 2015), the Batanes Islands and the Cagayan Valley in the northern Philippines (Bellwood and Dizon 2013; Hung et al. 2011), the Mariana Islands (Carson 2014; Carson and Hung 2017; Carson et al. 2013), and Sulawesi (Anggraeni et al. 2014; see also Bellwood 2011, 2017; Bellwood et al. 2011). The recent discovery of the most widespread Polynesian mitochondrial DNA haplotype, and a northern Island Southeast Asian autosomal ancestry signature, in the DNA of three 3000-year-old Lapita crania from the site of Teouma in Vanuatu (Bedford et al. 2018; Lipson et al. 2018; Posth et al. 2018; Skoglund et al. 2016) strongly supports a biological genesis of Polynesians somewhere northwest of New Guinea. Modern archaeological data also indicate that the closest parallels for Lapita pottery occur in the Philippine and Mariana Islands (Carson et al. 2013), with a possible extension into northern Sulawesi (Ono, Aziz et al. 2017:118; Ono, Oktaviana et al. 2017; Ono, Sofian et al. in press).

However, neither the Northern Moluccas nor the Talaud Islands have so far produced any archaeological materials that are closely related to Lapita or early Marianas pottery decoration. Therefore, while in 1990 I might have considered the Northern Moluccas and the northern coastline of New Guinea to have offered a major passageway into Oceania for the migrations of the Austronesian-speaking peoples, and especially the ancestral Polynesians, I have to state that I am no longer so enthusiastic about this likelihood today (Bellwood 2017:Chapter 8). Moluccan archaeology in 2018 needs to find its own relevance from other sources, and hopefully this monograph will show how it can. One aspect of particular relevance is that these islands were a meeting place for speakers of Papuan and Austronesian languages between 3500 and 2000 years ago, and the archaeological record related to the first appearance of pottery seems to reflect this meeting fairly clearly (Ono, Aziz et al. 2017; Ono, Oktaviana et al. 2017).

There is, of course, a lot more to Northern Moluccan archaeology than Neolithic pottery and possible links with Lapita and New Guinea. Fifty years ago, rather little was known also about the Late Palaeolithic in Island Southeast Asia, beyond the schematically published findings from the Tabon and Niah Caves, in Palawan and Sarawak respectively (see contemporary summaries in Bellwood 1978). So, it is gratifying to note that the North Moluccan project described in this monograph has contributed not just to Neolithic issues, but also much information on the putatively modern human (Homo sapiens) colonisation of Wallacea as much as 40,000 years ago (Szabó et al. 2007). Golo and Wetef Caves on Gebe Island, in particular, have yielded important Palaeolithic data.

As well as site reports, this monograph also contains specialist reports on the human remains, animal bones and shell artefacts that were recovered from many sites, and we are now considering the implications of ancient human DNA data from the sites of Uattamdi and Tanjung Pinang, courtesy of the Max Planck Institutes for Evolutionary Anthropology in Leipzig and the Science of Human History in Jena, Germany. Although the excavations described in this monograph took place more than 20 years ago, there are sufficient new data to encourage a thorough presentation of all the results, new and old, in a single venue. This monograph is that venue. 


\section{The Indonesian-Australian Archaeological Research Project in the Northern Moluccas, 1990 to 1996}

In 1977, three years after my first Indonesian research project with I Made Sutayasa in Minahasa and the Talaud Islands, I approached the late Professor R.P. Soejono, former head of the National Archaeological Research Centre in Jakarta (then called Lembaga Purbakala dan Peninggalan Nasional), with a proposal to commence research in the Northern Moluccas. Soejono indicated that permits would be hard to obtain for various reasons beyond his control, connected with the general political atmosphere between Indonesia and Australia at that time. I decided to move my interests for the next decade to Sabah (Bellwood 1988). By 1990, the situation in Indonesia had brightened, and while I was a member of the Comparative Austronesian Project at The Australian National University (ANU), led by James Fox (Bellwood et al. 2006), I was able to apply successfully for a research permit from Lembaga Ilmu dan Pengetahuan Nasional (LIPI) and the Archaeological Research Centre in Jakarta (by this time renamed Pusat Penelitian Arkeologi Nasional). Geoffrey Irwin and I landed in Ternate to begin our research in December 1990, in company with Gunadi Nitihaminoto, Agus Waluyo, Gunadi Kusnowihardjo and the late Haji Syamsuddin Tukuboya. Four field seasons followed, in 1990-91, 1994 (twice), and 1995-96.

During the 1990s, and up until 2007, a number of excavation and other specialist reports were published on the results of the North Moluccan archaeological project (see the list below), but the results have never been brought together as a whole into one single definitive publication. This scattering of data has been a little unfortunate, especially since a 40,000-year record of prehistoric human activity from one close-set group of relatively small Wallacean islands has not exactly been an everyday occurrence in the archaeology of Island Southeast Asia. This retrospective account of the North Moluccan archaeological project, prepared during 2013-18, or roughly 25 years after the project's commencement, will attempt to make the data (much previously unpublished) accessible and useful for future generations of archaeologists, especially Indonesian archaeologists who might wish one day to continue research in the region. It is intended to provide a kind of road map for those who wish to access the existing published reports, as well as offering some conclusions of an interpretative and chronological nature. Many new perspectives are apparent 25 years after the actual field research, and now is the time to bring them forth.

The monograph opens with a full account of the many excavations undertaken by the project, presenting basic field data and chronologies. Successive chapters are focused on pottery, lithic artefacts, shell artefacts, zooarchaeology, and human skeletal analysis and health. The volume finishes with a review chapter by Bellwood on the whole prehistoric record of the Northern Moluccas in its Island Southeast Asian and Oceanic setting. Detailed information that has been published previously is not necessarily always repeated, but a conscious attempt is made to bring all pertinent data together in a single presentation format, using references to other published material as necessary.

No attempt is made in this monograph to give an overall introduction to Moluccan natural history, but a few preliminary generalisations are warranted. The Northern Moluccas are entirely equatorial, located within 3 degrees north and south of the Equator, with no marked dry season. Monsoon winds vary seasonally, blowing generally from the north or northeast in the northern hemisphere winter (January) and from the south or southeast in the southern hemisphere winter (July). Vegetation is wet rainforest, except on very poor soils.

A major volcanic arc runs down the western side of Halmahera Island, and the Jailolo region of Halmahera, plus the islands of Ternate, Tidore and Makian, still have active volcanoes. Halmahera itself has rugged uplifted interior terrain incorporating sedimentary and metamorphic rocks of late Mesozoic age and onwards (Hall et al. 1988). Along the eastern coastlines of 
Morotai, Halmahera and Gebe, raised coral reefs are common. The Halmahera island complex can therefore be conceptualised as a westerly arc of active volcanoes, against which a separate uplifted easterly arc, without current volcanic activity, has been forced by subduction and plate movement. The result is the unusual spider shape of the island of Halmahera, rather similar to that of the much larger Sulawesi that lies to the west.

Native mammals prior to human arrival were possibly restricted to placental rodents and bats of ultimate Eurasian (Sunda) origin, and marsupial sugar gliders and cuscuses of ultimate Australasian (Sahul) origin (Flannery 1995a). Question marks hover around marsupial wallabies and bandicoots, as discussed in Chapter 10. Did the marsupials, including perhaps even the cuscuses, arrive by natural means or by human translocation?

By $1500 \mathrm{CE}$, the Spice Islands were entering the consciousness of Western civilisations as a source of spices, especially cloves and nutmegs. Hence the arrivals of Portuguese, Dutch, and eventually Indonesian systems of political interference and control (Andaya 1993; Cortesão 1944; Wallace 1869). The post- 1500 historical era is not particularly relevant for the contents of this monograph, and none of the excavated sites have significant material culture from this time. However, questions are raised about the role of the Moluccas in spice trading (especially cloves, of Northern Moluccan origin) much earlier, especially with the inception of contacts between Indonesia and India around 2000 years ago.

It remains to list the personnel and funding agencies that made the project a success. The research project formally entitled 'Archaeological Survey and Excavation in the Halmahera Islands, Moluccas, Indonesia', with fieldwork carried out between 1990 and 1996, was funded by the National Geographic Society and the Australian Research Council. It involved cooperation between five institutions: the Department of Archaeology and Anthropology at ANU, the Indonesian National Research Centre of Archaeology (then termed Pusat Penelitian Arkeologi Nasional), the Department of Anthropology at Auckland University, the (then) Indonesian Directorate of Protection and Development of Historical and Archaeological Heritage, and the Sultan Palace Museum in Ternate. The fieldwork was undertaken in four phases: December 1990 to February 1991, January to February 1994, May to June 1994, and December 1995 to January 1996. Major team members were as follows, with their places of residence at the time of the research: Peter Bellwood (Canberra), Geoffrey Irwin (Auckland), Agus Waluyo (Jakarta), Gunadi Nitihaminoto, Gunadi Kusnowihardjo, Daud Tanudirjo (all Yogyakarta), the late Haji Syamsuddin Tukuboya (Ternate), and Joko Siswanto (Manado). Analytical expertise was also provided during the 1990s by Tim Flannery (identification of marsupials and rodents), Peter White (analysis of animal bones), Doreen Bowdery (analysis of phytoliths), and David Bulbeck (analysis of human remains). The ANU, ANSTO (Australian Nuclear Science and Technology Organisation), New Zealand and Waikato Radiocarbon Dating laboratories analysed the radiocarbon dates, as listed in Table 1.1 below. We thank Stewart Fallon and Rachel Wood of the ANU Dating Laboratory for recent discussions about matters of C14 date interpretation.

Many of the figures were originally drawn on tracing paper by hand during the 1990s, with some of the lettering replaced for clarity using Adobe Illustrator. Some figures are completely new, and most (except where otherwise credited) were prepared using Illustrator or digital scans of original $35 \mathrm{~mm}$ slides by Peter Bellwood. Some of the illustrations therefore have an 'archival' feel, but to maintain accuracy no unnecessary redrawing has been attempted.

This Terra Australis monograph has been published with the aid of a subsidy from the ANU Publication Subsidy Committee. 


\section{Articles previously published from this project on the archaeology of the Northern Moluccas}

At this point in the introductory chapter, it will be useful to present a list of all the previous publications related to this project. Most date from the 1990s and represent opinions published quite soon after the completion of the relevant fieldwork. Not all reflect completely the current perspectives that are presented in this monograph, and it can often be informative to observe just how interpretations can change as new information appears. The articles are in chronological order, from 1992 onwards.

Bellwood, P. 1992. New discoveries in Southeast Asia relevant for Melanesian (especially Lapita) prehistory. In J.C. Galipaud ed., Poterie Lapita et Peuplement, pp. 49-66. Nouméa: ORSTOM. (This article was the first to be published on the Maluku Project, following the first period of fieldwork in 1990-91, when excavations took place in the important sites of Uattamdi, Tanjung Pinang, and Gua Siti Nafisah.)

Bellwood, P., A. Waluyo, Gunadi, G. Nitihaminoto and G. Irwin 1993. Archaeological research in the Northern Moluccas; interim results, 1991 field season. Bulletin of the Indo-Pacific Prehistory Association 13:20-33.

Bellwood, P. 1995. Archaeological research in the Northern Moluccas 1991-1994: a preliminary report. Southeast Asian Archaeology International Newsletter 7:3-12.

Flannery, T., P. Bellwood, P. White, A. Moore, Boeadi and G. Nitihaminoto 1995. Fossil marsupials (Macropodidae, Peroryctidae) and other mammals of Holocene age from Halmahera, North Moluccas, Indonesia. Alcheringa 19:17-25.

Mahirta 1996. The development of the Mare pottery tradition. Bulletin of the Indo-Pacific Prehistory Association 20: 124-132.

Bellwood, P. 1998. From Bird's Head to bird's eye view: long term structures and trends in Indo-Pacific Prehistory. In J. Miedema, C. Odé and R. Dam (eds), Perspectives on the Bird's Head of Irian Jaya, Indonesia, pp. 951-975. Amsterdam: Rodopi.

Flannery, T., P. Bellwood, J.P. White, T. Ennis, G. Irwin, K. Schubert and S. Balasubramanian 1998. Mammals from Holocene archaeological deposits on Gebe and Morotai Islands, Northern Moluccas, Indonesia. Australian Mammalogy 20/3:391-400.

Bellwood, P., G. Nitihaminoto, G. Irwin, Gunadi, A. Waluyo and D. Tanudirjo 1998. 35,000 years of prehistory in the Northern Moluccas. In G.-J. Bartstra (ed.), Bird's Head Approaches, pp. 233-275. Modern Quaternary Research in Southeast Asia 15. Rotterdam: Balkema.

Bellwood, P. 1998. Between Southeast Asia and Oceania: preceramic occupation in the Northern Moluccas and associated mysteries. In Jejak-Jejak Budaya II: Persembahan untuk Prof. Dr. R.P. Soejono, pp. 323-369. Yogyakarta: Asosiasi Prehistorisi Indonesia Rayon II.

Bellwood, P. 1998. The archaeology of Papuan and Austronesian prehistory in the Northern Moluccas, Indonesia. In R. Blench and M. Spriggs (eds), Archaeology and Language, Volume 2: Correlating Archaeological and Linguistic Hypotheses, pp. 128-140. London: One World Archaeology Series, Routledge.

Irwin, G., P. Bellwood, G. Nitihaminoto, D. Tanudirjo and J. Siswanto 1999. Prehistoric relations between Island Southeast Asia and Oceania: recent archaeological investigations in the Northern Moluccas. In J.-C. Galipaud and I. Lilley eds, The Pacific from 5000 to 2000 BP, pp. 363-374. Paris: Institut de Recherche pour le Développement. 
Bellwood, P., G. Nitihaminoto, Gunadi, A. Waluyo and G. Irwin 2000. The Northern Moluccas as a crossroads between Indonesia and the Pacific. In Sudaryanto and A.H. Rambadeta (eds), Antar Hubungan Bahasa dan Budaya di Kawasan Non-Austronesia, pp. 195-254. Yogyakarta: Pusat Studi Asia Pasifik.

Pasveer, J. and P. Bellwood 2004. Prehistoric bone artefacts from the Northern Moluccas, Indonesia. Modern Quaternary Research in Southeast Asia 18:301-359.

Bellwood, P. and P. White 2005. Domesticated pigs in eastern Indonesia. Science 309:381.

Szabó, K., A. Brumm and P. Bellwood 2007. Shell artefact production at 32,000 BP in Island Southeast Asia: thinking across media? Current Anthropology 48:701-724.

Szabó, K. and B. Koppel 2015. Limpet shells as unmodified tools in Pleistocene Southeast Asia: an experimental approach to assessing fracture and modification. Journal of Archaeological Science 54:64-76.

There are in addition three Master's theses:

Mahirta. 2000. The Development of Mare Pottery in the Northern Moluccas Context. Unpublished MA thesis, The Australian National University.

Hull, Jennifer R. 2014. The Vertebrate Remains Recovered During the 1990-1996 Excavations of the Northern Moluccan Islands. Unpublished Master of Archaeological Science subthesis, The Australian National University.

Wyatt, Bronwyn 2017. Health and Disease in Prehistoric Indonesia: Placing the Northern Moluccas Islands into Context Within Broader Southeast Asian Prehistory. Unpublished Master of Biological Anthropology subthesis, The Australian National University.

\section{Checklist of radiocarbon dates from the Northern Moluccas (Peter Bellwood and Rachel Wood)}

A total of 77 radiocarbon dates were assembled during the course of this project, and these are referred to frequently throughout the text and in the tables for each excavated site. For convenience, the total series is listed here, by site, in Table 1.1. Many are listed again in the tables in the following excavation chapters.

Within tables that list radiocarbon dates, the convention cal. BP (for calibrated years before present) is used for calibrated dates. In the general text, the abbreviations $\mathrm{BCE}$ and $\mathrm{CE}$ (Before Common Era and Common Era) are used to replace BC and AD.

The information in this table has been updated where relevant by Rachel Wood (Radiocarbon Dating Laboratory, Research School of Earth Sciences, The Australian National University) and Fiona Petchey (Radiocarbon Dating Laboratory, Waikato University, New Zealand). 


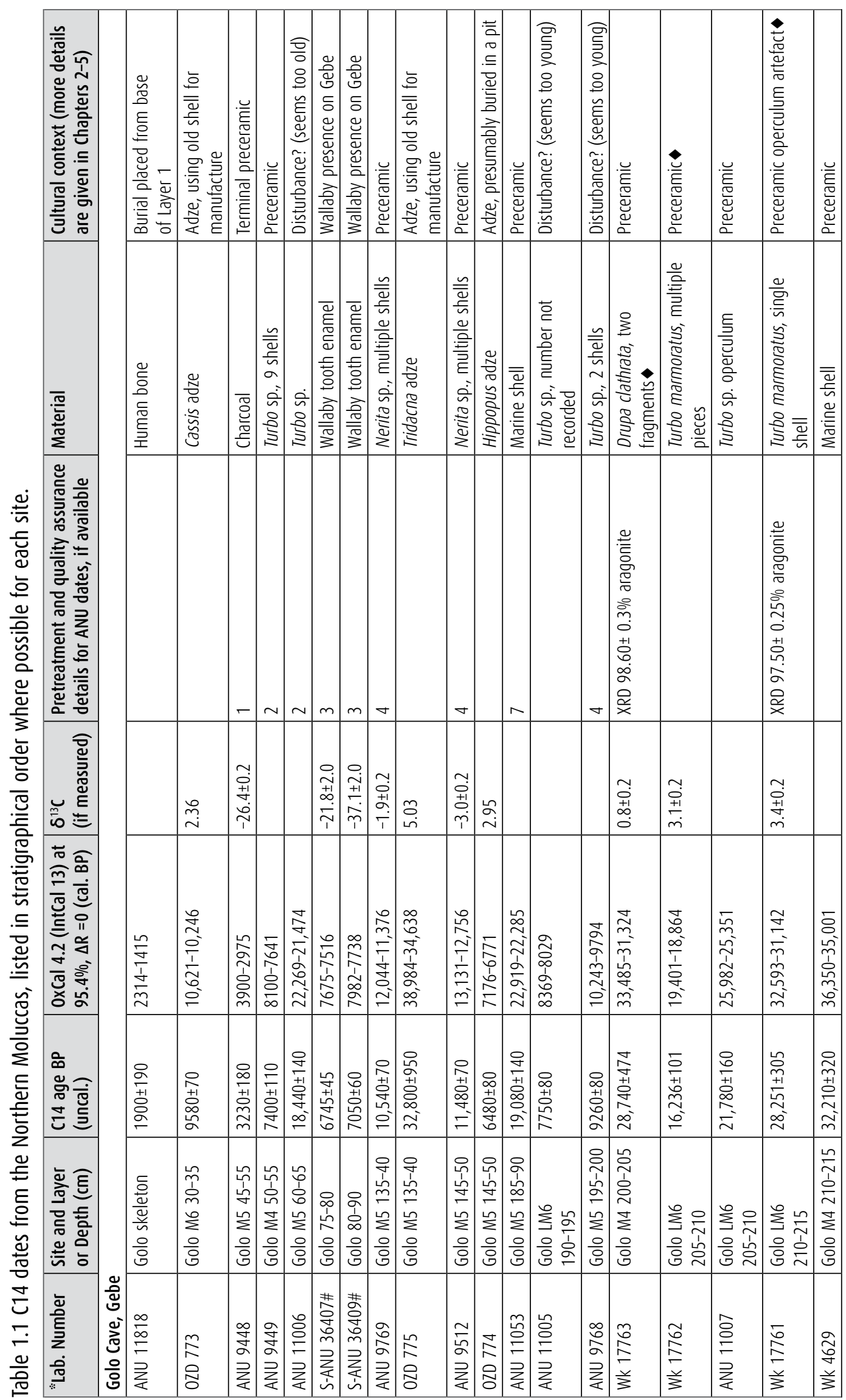




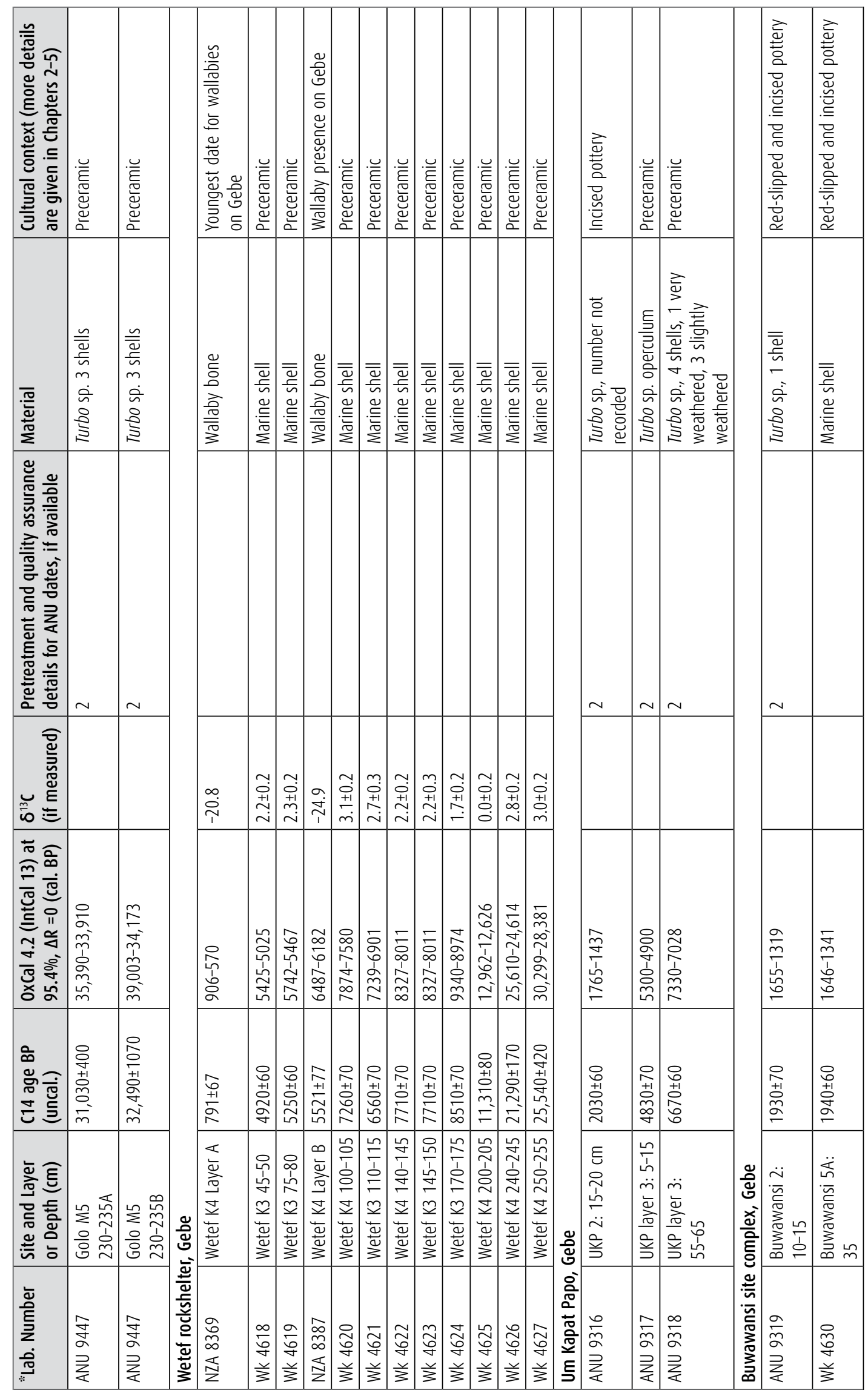




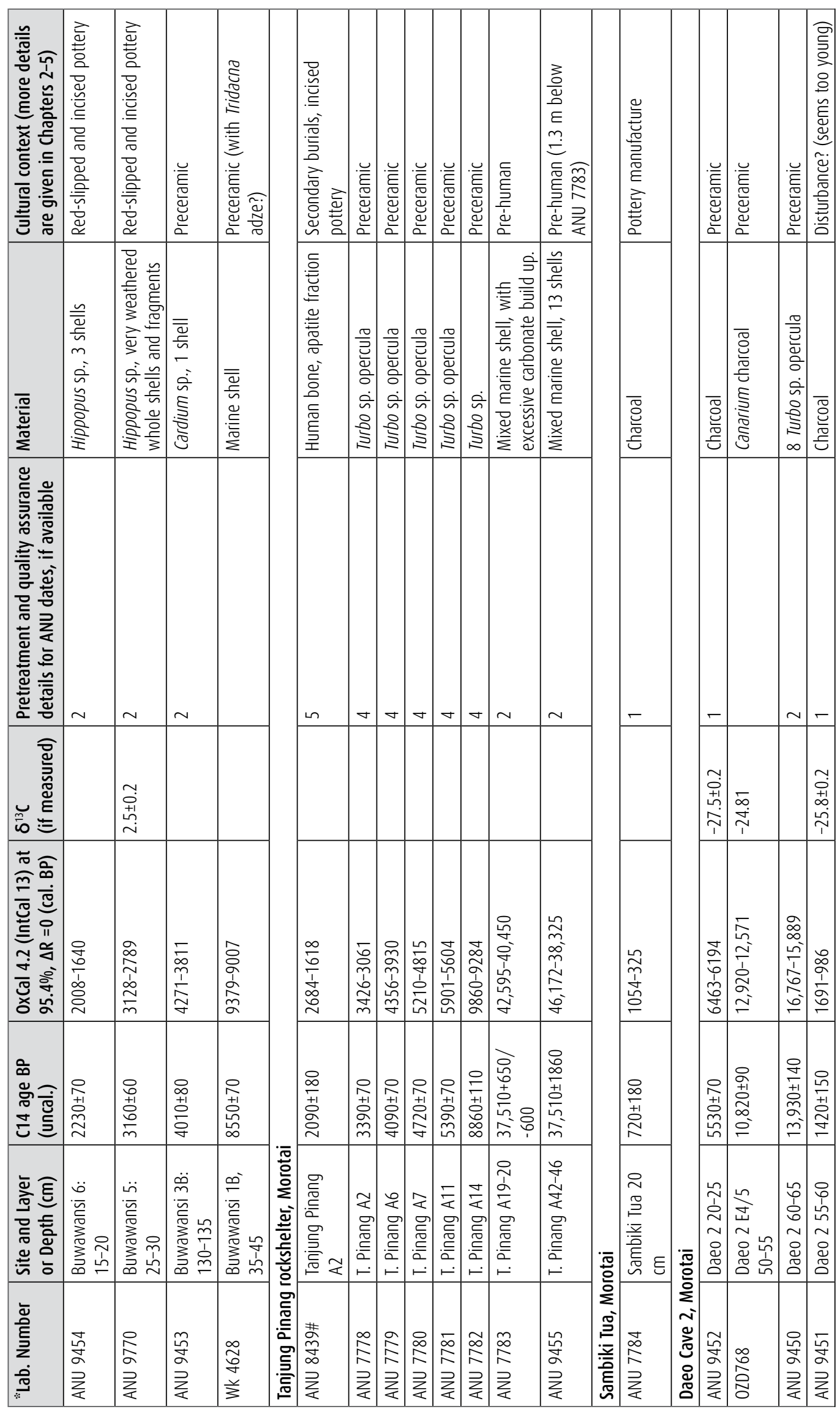




\begin{tabular}{|c|c|c|c|c|c|c|c|c|c|c|c|c|c|c|c|c|c|c|}
\hline 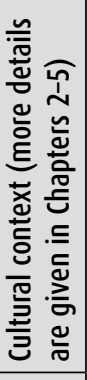 & & 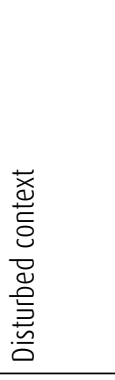 & 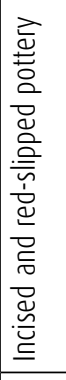 & 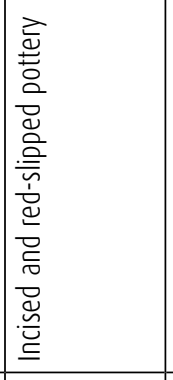 & 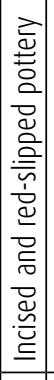 & 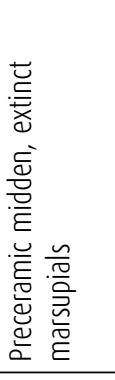 & 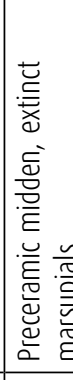 & 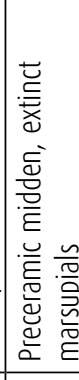 & 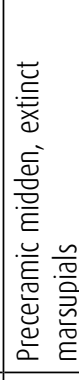 & & 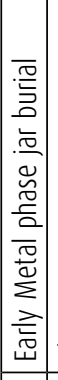 & 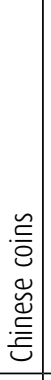 & $\begin{array}{l}\tilde{\tilde{\Xi}} \\
\tilde{\Xi} \\
\tilde{\tilde{\sigma}} \\
\tilde{\sigma} \\
\end{array}$ & 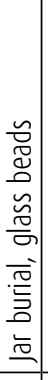 & 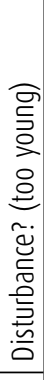 & 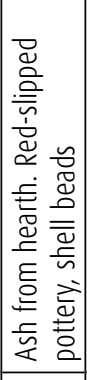 & 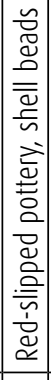 & 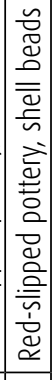 \\
\hline 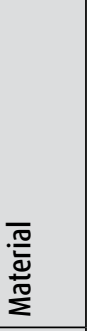 & & 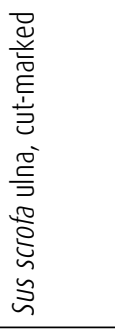 & 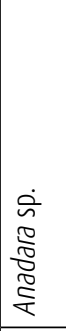 & 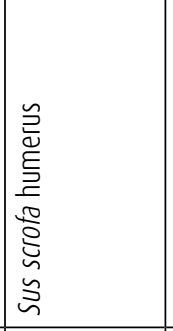 & 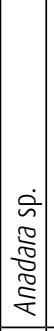 & 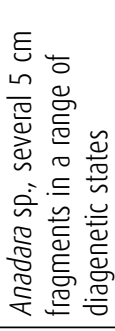 & 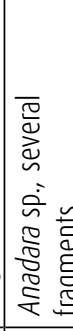 & 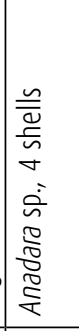 & 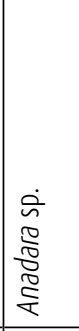 & & 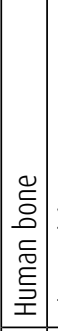 & 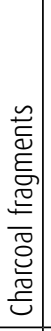 & 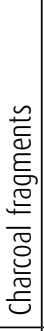 & 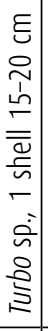 & 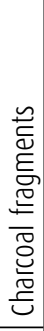 & 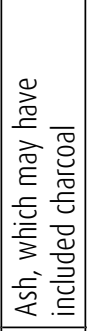 & 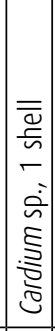 & 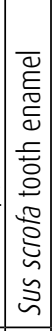 \\
\hline 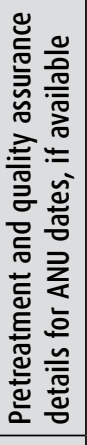 & & 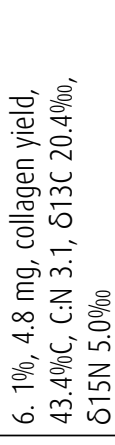 & $\sim$ & 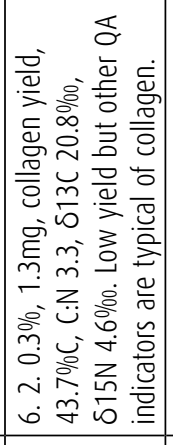 & $\sim$ & $\sim$ & $\nabla$ & $\sim$ & $\sim$ & & & - & - & $\sim$ & - & - & $\sim$ & $\stackrel{\infty}{m}$ \\
\hline 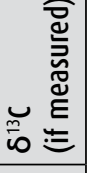 & & 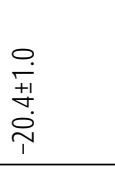 & 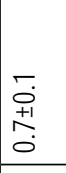 & $\begin{array}{l}0 \\
0 \\
+1 \\
\infty \\
0 \\
\stackrel{T}{T} \\
\end{array}$ & & & & & & & $\mid \begin{array}{c}0 \\
0 \\
0 \\
1 \\
\end{array}$ & & & & & & & $\begin{array}{l}\stackrel{0}{\sim} \\
\stackrel{\sim}{T} \\
\end{array}$ \\
\hline 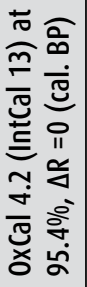 & & 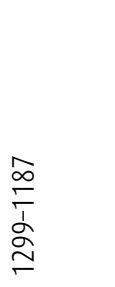 & 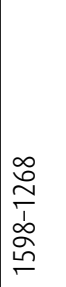 & 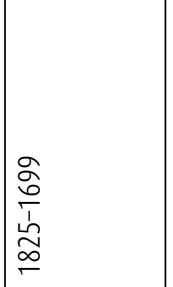 & 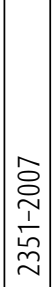 & 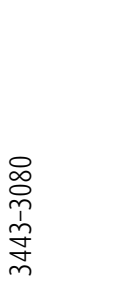 & 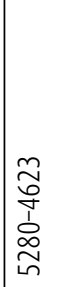 & 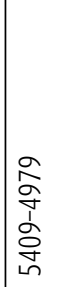 & 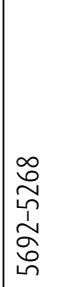 & & 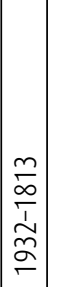 & $\begin{array}{l}0 \\
0 \\
0 \\
+ \\
0 \\
0\end{array}$ & 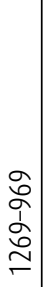 & 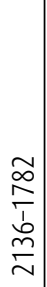 & 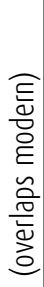 & 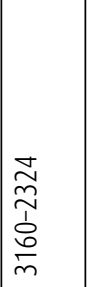 & $\begin{array}{l}\tilde{D} \\
\tilde{D} \\
\tilde{N} \\
\tilde{N} \\
\tilde{N}\end{array}$ & 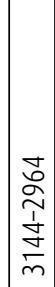 \\
\hline 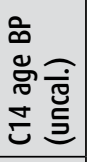 & & 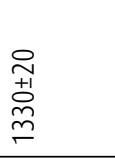 & \begin{tabular}{l}
0 \\
$\infty$ \\
01 \\
0 \\
$\infty$ \\
$\infty$ \\
\hdashline \\
\end{tabular} & $\begin{array}{l}\stackrel{\stackrel{\sim}{\sim}}{+1} \\
\stackrel{1}{\sim} \\
\stackrel{\infty}{\infty} \\
\sim\end{array}$ & 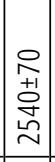 & $\begin{array}{l}\stackrel{P}{2} \\
\text { 蒿 } \\
\stackrel{5}{m} \\
\end{array}$ & 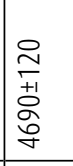 & 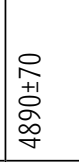 & $\begin{array}{l}8 \\
0 \\
+1 \\
\stackrel{0}{2} \\
\text { in }\end{array}$ & & 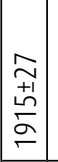 & 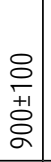 & 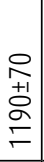 & 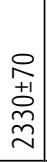 & $\begin{array}{l}\frac{\Omega}{2} \\
\frac{1}{+1} \\
\stackrel{2}{m}\end{array}$ & $\begin{array}{l}\frac{2}{2} \\
\frac{1}{+1} \\
\frac{0}{2} \\
\sim\end{array}$ & 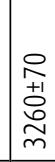 & 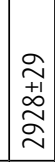 \\
\hline 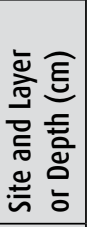 & 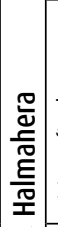 & 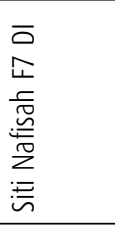 & 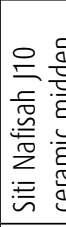 & 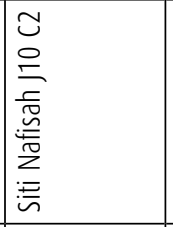 & 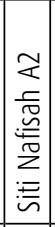 & 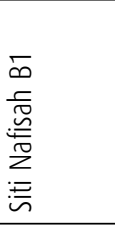 & 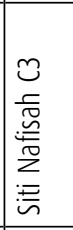 & 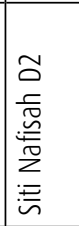 & 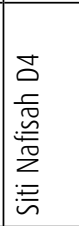 & & 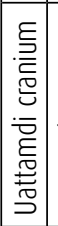 & 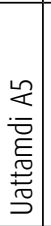 & 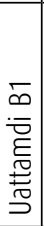 & 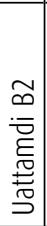 & 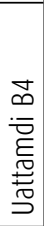 & 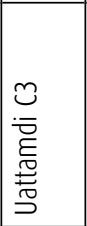 & 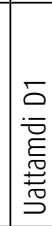 & 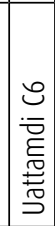 \\
\hline 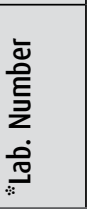 & $\mid$ & 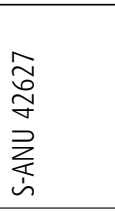 & $\begin{array}{l}\stackrel{2}{2} \\
\stackrel{1}{\curvearrowright}\end{array}$ & 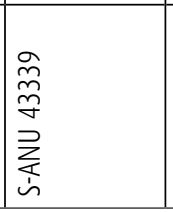 & 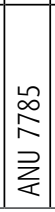 & 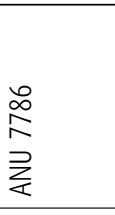 & 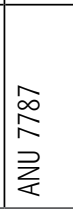 & 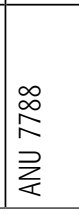 & $\begin{array}{l}\stackrel{\infty}{\infty} \\
⿱ 亠 乂 \\
⿱ 亠 幺\end{array}$ & 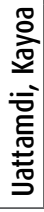 & 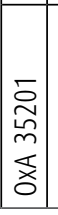 & 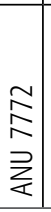 & $\begin{array}{l}\stackrel{\Sigma}{\Sigma} \\
⿱ 亠 \\
\sum \\
\Sigma\end{array}$ & $\begin{array}{l}\widetilde{\approx} \\
\approx \\
ٍ\end{array}$ & 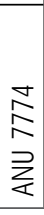 & $\mid \begin{array}{l}\underset{N}{N} \\
\sum \\
\sum\end{array}$ & $\begin{array}{l}\text { } \\
\text { مे } \\
\sum_{z}\end{array}$ & $\begin{array}{l}8 \\
0 \\
0 \\
2 \\
2\end{array}$ \\
\hline
\end{tabular}




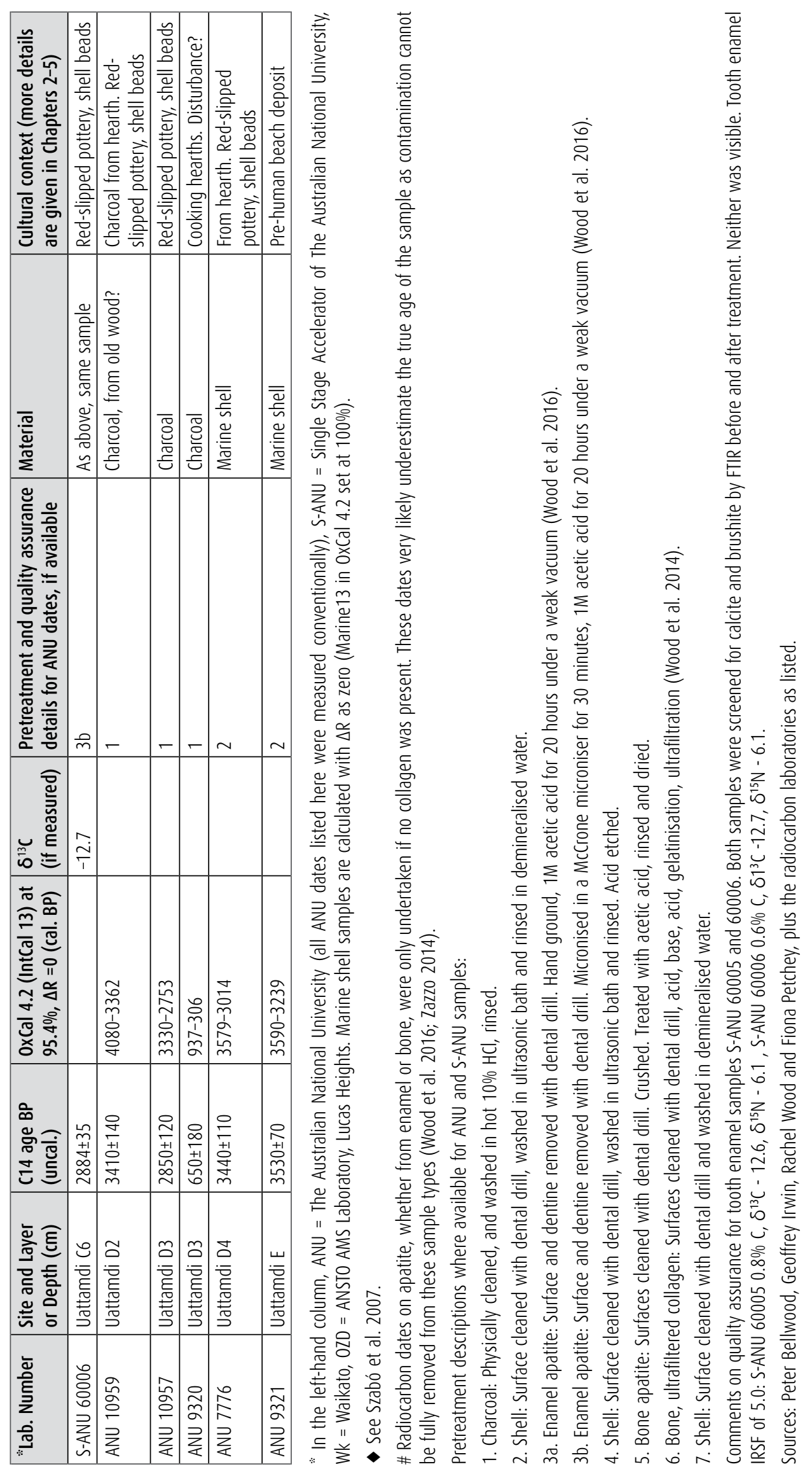


This text is taken from The Spice Islands in Prehistory: Archaeology in the Northern Moluccas, Indonesia, edited by Peter Bellwood, published 2019 by ANU Press, The Australian National University, Canberra, Australia.

doi.org/10.22459/TA50.2019.01 